\title{
Future career interest in science, gender and students' acquisition of science process skills in basic science in Oyo state, Nigeria
}

\author{
Ogunkunle Segun Jacob * \\ Department of Integrated Science Federal College of Education (Special), Oyo, Nigeria
}

\author{
Keywords \\ Future career \\ Basic science \\ Simulated laboratory \\ Enriched \\ Laboratory guide \\ Science process skill
}

Received: 7 June 2018

Accepted: 19 July 2018

Published: 9 August 2018

\begin{abstract}
This study examined the effects of future career interest in science and gender, both used as moderator variables, on students' acquisition of science process skills when taught Basic Science with simulated laboratory and enriched laboratory guide material experiments. It adopted the pretest-posttest control group quasi-experimental design with a 3x2x2 factorial matrix. Participants in the study included 277 (130 males, 147 females; $\pm 17 y e a r s$ ) junior secondary three students randomly selected from six purposively chosen secondary schools based on the existence of functional computer and physics laboratories. Science process skills test in Basic Science $(r=0.72)$ and Future career interest in science questionnaire $(r=0.99)$ were used to collect the data, which were processed using analysis of covariance and estimated marginal means in order to test three null hypotheses at 0.05 level of significance. Future career interest in science significantly affected students' science process skills acquisition in Basic Science. At the same time, there was none for gender nor interaction effect between future career interest in science and gender. Thus, students' acquisition of science process skills depends largely on future career interest in science which determines effective participation in Basic Science activities, especially laboratory experiments. It is recommended that teachers are acquainted with students' future career interests in science and utilize the same to encourage effective participation in Basic Science practicals. This could assist students in acquiring science process skills needed to experience and practice science for better performance in biology, chemistry, and physics at the post-basic education level in Nigeria.
\end{abstract}

(C) 2018 The Author(s). Published by TAF Publishing.

\section{INTRODUCTION}

Science Process Skills (SPS) are the essential instruments required for the generation and study of scientific knowledge. They are thinking skills used by scientists to construct knowledge for the purpose of solving problems (Keong, Yip, Swee, Toh, \& Tai, 2017; Ozgelen, 2012; Rex, Yetunde, Grace, \& Pearl, 2017). They are important to scientists because the primary concerns of science are problem-seeking and problem-solving (Blough \& Schwartz, 1974).

SPS's are tools that individuals use to acquire, process and order information about the world (Ostlund, 1992). They comprise cognitive and psychomotor skills employed to identify and evaluate problems; collect, transform and interpret data; as well as communicate results and findings during problem-solving (Akinbobola \& Afolabi, 2010). They equipped students with competencies needed for conducting research in science and critical thinking in life generally. They affect personal, social and global lives of individuals (Aktamis \& Ergin, 2008). Therefore, the development of SPSs enables students to acquire skills necessary for solving everyday problems (Kazeni, 2005).

The American Association for the Advancement of Science (AAAS) identify fourteen process skills. Ozgelen (2012) reported that SPSs had been grouped into basic and integrated to the Science-A Process Approach (SAPA) Curriculum project. Basic SPSs include: observing, using space/time relationships, inferring, measuring, communicating, classifying and predicting. Integrated SPSs consist

${ }^{*}$ corresponding author: Ogunkunle Segun Jacob

†email: kunlejacob@yahoo.com 
of controlling variables, defining operationally, formulating hypotheses, interpreting data, experimenting, formulating models and presenting information. Basic SPSs are prerequisites for learning integrated SPSs and development of problem-solving abilities in science. Thus, Tobin and Capie (1982) recommend that pre-secondary education (concrete operational stage) should ensure acquisition of SPSs preparatory to the development of integrated SPSs in the secondary schools (formal operational stage). This is corroborated by the positive and high correlation $(r=0.73)$ between students' integrated SPSs and formal operational skills reported by Padilla, Okey, and Dillashaw (1983).

SPSs are acquired in the laboratory. Science researches are carried out in the laboratories. A laboratory is a space with or without physical boundaries. It may be real or virtual. It is a medium for instruction in science teaching and learning. It provides students with opportunities to engage in processes of investigation and enquiry. This implies that a laboratory is an environment which facilitates learning by doing and consequently development of SPSs in the students.

Utami, Saputro, Ashadi, Yamtinah, and Widoretno (2017) reported that observing, data recording, communicating, inferring, experimenting and data interpreting manifested in that order as SPSs which were developed when grade II senior high school Indonesia studen were tautht rate of reaction in chemistry. Also, Ige and Fasasi (2009) established a significant effect of laboratory work on SPSs acquisition in senior secondary two agricultural science in Nigeria. Thus, SPSs are developed during laboratory activities/works.

Laboratory activities are "learning experiences in which students interact with materials and/or with models to observe and understand the material world" (Hofstein \& Lunetta, 2004). They include "minds-on" and "hands-on" activities. They are mostly laboratory experiments and field works (science projects).

The development of SPS's depends on availability of functional laboratory and learners' interest in participating in laboratory experiments among others. However, there are no Basic Science (BS) laboratories nor enriched laboratory guide materials for conducting laboratory experiments in most basic education schools in Nigeria. Ajeyalemi (2011) observes that more than $90 \%$ of Nigeria public schools neither have laboratory space and/or equipment nor are supplied with necessary science kits for practical activities intended in the curriculum. This situation makes many Nigeria junior secondary schools to convert ordinary classrooms to BS laboratories or use the senior secondary school sci- ence laboratories to conduct practical in BS. Unfortunately, the laboratories are ill-equipped and have inadequate consumables. This is corroborated by the findings of Eya and Elechi (2011) that secondary school teachers in the six education zones of Enugu State did not utilise laboratory facilities to teach BS because of lack of adequate laboratory facilities, lack of teacher's guide and practical manuals.

In order to make students experience science through constant involvement in laboratory works so that they can acquire SPSs, Shaheen and Khattab (2005) advocate the use of Simulated Laboratory (SL) experiments to reduce the challenges of absence of BS laboratories as well as nonavailability of materials and equipment in senior secondary laboratories. Ogunbowale (2012) recommends the deployment and use of Enriched Laboratory Guide Material (ELGM) in all science laboratory experiments.

SL experiment is an application of Computer Assisted/Aided Learning (CAL) to conducting experiments in the laboratory (Akani, 2005). Ige and Ele (2009) identify the following roles and values of using Information and Communication Technology (ICT) in science teaching and learning among others:

i. Foster students' interest and motivation.

ii. Promote students commitment to learning.

iii. Make the lessons exciting and interesting for both teachers and students.

iv. Make students to do science effectively and conduct experiments as viewed on screen.

v. Facilitate the process of learning through interaction with simulation.

Research reports by Lazarowitz and Huppert (2014) as well as Yang and Heh (2007) indicate that SL experiments enhance students' SPSs acquisition in microbiology and physics respectively.

ELGM experiment is the use of a carefully prepared experimental procedure to explore in order to discover relationship(s) between experimental variables in a functional physical or simulated (virtual) laboratory. ELGM facilitates smooth and hitch-free conduct of laboratory experiments. Research findings reveal that ELGM experiments promote acquisition of SPSs in chemistry (Chebii, Wachanga, \& Kiboss, 2012).

Many Nigerian students do not show interest in the study of senior secondary science subjects. This is evident in the outcome of a comparison between students' participation in BS and senior secondary science subjects as presented in Table 1. 
TABLE 1. Transition rates from basic Science to the senior secondary chemistry and physics in Oyo state

\begin{tabular}{lllll}
\hline \hline BECE & & WASSCE & & \multirow{2}{\%}{$\begin{array}{c}\text { Population of BECE graduates who } \\
\text { took science subjects (C=B/AX100\%) }\end{array}$} \\
\cline { 1 - 3 } Year Taken & Population (A) & Year Taken & Science Population (B) & 18.9 \\
\hline 2008 & 80,070 & 2011 & 15,163 & 16.1 \\
2009 & 85,034 & 2012 & 13,724 & 33.7 \\
2010 & 80,355 & 2013 & 27,111 & \\
\hline \hline
\end{tabular}

Notes: Department of Planning, Research and Statistics, Oyo State Ministry of Education, Secretariat, Ibadan, Oyo State (2015)

Table 1 indicates that $18.9 \%, 16.1 \%$ and $33.7 \%$ of the BS graduates offered and sat for one or both of chemistry and physics in the West African Senior School Certificate Examinations (WASSCE) in 2011, 2012 and 2013 respectively.
This is in spite of impressive performance in the Basic Education Certificate Examination (BECE) in BS for junior secondary (JS) students between 2008 and 2015 in Oyo State (as contained in Table 2).

TABLE 2. Analysis of Oyo state students' performance in the BECE in basic science (2008-2015)

\begin{tabular}{lllllll}
\hline \hline Year & Total Candidate & Distinction (A) & Credit (C) & Pass (P) & Failure (F) & A+C \\
\hline 2008 & $80,070(100.0 \%)$ & $8,056(10.0 \%)$ & $51,627(64.5 \%)$ & $14,138(17.7 \%)$ & $6,249(07.8 \%)$ & $59,683(74.5 \%)$ \\
2009 & $85,034(100.0 \%)$ & $9,740(11.5 \%)$ & $37,347(43.9 \%)$ & $29,935(35.2 \%)$ & $8,012(09.4 \%)$ & $47,087(55.4 \%)$ \\
2010 & $80,355(100.0 \%)$ & $11,073(13.8 \%)$ & $50,435(62.8 \%)$ & $18,081(22.5 \%)$ & $766(01.0 \%)$ & $61,508(76.5 \%)$ \\
2011 & $75,437(100.0 \%)$ & $16,517(21.9 \%)$ & $27,962(37.1 \%)$ & $15,640(20.7 \%)$ & $15,318(20.3 \%)$ & $44,479(59.0 \%)$ \\
2012 & $89,047(100.0 \%)$ & $8,554(09.6 \%)$ & $44,345(49.8 \%)$ & $25,466(28.6 \%)$ & $10,682(12.0 \%)$ & $52,899(59.4 \%)$ \\
2013 & $78,733(100.0 \%)$ & $259(00.3 \%)$ & $46,873(59.6 \%)$ & $20,723(26.3 \%)$ & $10,878(13.8 \%)$ & $47132(59.9 \%)$ \\
2014 & $89,108(100.0 \%)$ & $6867(07.7 \%)$ & $62,796(70.5 \%)$ & $17,988(20.2 \%)$ & $1,457(01.64 \%)$ & $69663(78.2 \%)$ \\
2015 & $96,421(100.0 \%)$ & $11,348(11.77 \%)$ & $65,541(67.97 \%)$ & $19,501(20.23 \%)$ & $31(00.03 \%)$ & $76,889(79.74 \%)$ \\
\hline \hline
\end{tabular}

Source: Oyo State Government (2015)

Thus, BS has not adequately developed students' interest in science as implied in the low enrolment in post-basic science education. Perhaps, this is due to inadequate exposure to BS practical which has given rise to students' deprivation to experience and enjoy science. This corroborates Ekpunobi (2005) observation that for a child to be science inclined, the foundation has to be effectively laid at the basic education level. Also, it undermines the achievement of one of the overall objectives of the basic education curriculum: "to enable the learners to become prepare for further studies in science and technology" (Nigerian Educational Research and Development Council, 2012).

However, it is important to arouse and sustain students' interest in BS laboratory experiments in order to boost enrolment in post-basic education science classes. This could be achieved by giving consideration to students' career interests during science lesson preparation and making its delivery enjoyable to the students.

Consequently, students will participate actively in laboratory activities and acquire SPSs better in this dispensation. According to İzzet Kurbanoğlu and Arslan (2015), career interest comprises resources which an individual uses to respond to tasks and challenges of vocational development.
These resources include adequate knowledge of the subject areas and their inherent life skills which are relevant to the actualization of the career interest. Thus, Future Career Interest in Science (FCIS) are preferences for science-related jobs, professions and works. They influence the choice of science subjects and disciplines at the post-basic education levels. They manifest as weak personal/individual interests which can be nurtured by conducive learning environment (situational interest) into strong individual interests in science activities.

Cheung (2018) views individual interest in science lesson as a relatively stable and enduring personal emotion comprising affective and behavioural reactions to events in the regular science lessons. It leads to an "enduring disposition to attend to certain objects and events and to engage in certain activities, contents or objects" (Hidi \& Renninger, 2006). Thus, FCIS motivates students to choose scienceand technology-related subjects and disciplines as well as promotes science students participation in laboratory activities.

This is corroborated by Hasni and Potvin (2015) view that FCIS determines the extent of students' current engagement in science activities and the level to which students 
have the intention to be involved in science activities in future. Therefore, SL and ELGM experiments environments have been selected and used to sustain students' FCIS for active involvement in laboratory activities in order to promote students' development of SPSs in BS.

Gender disparity in students' interest in science subjects, acquisition and possession of SPSs have been inconclusively reported in literature. Akani (2005) observes higher possession of SPSs by male than female students in Nigeria colleges of education. On the hand, Zeidan and Jayosi (2015) found females' possession of SPSs to be more than male students in first secondary grade in Turkey. Also, Ige and Fasasi discover that male students had better practical skills' acquisition in senior secondary two agricultural science than females. While female Turkish elementary school teachers recorded better SPSs acquisition than males (Aydogdu, Erkol, \& Erten, 2014). Trumper (2006a) reports that Israelis girls who were graduates of compulsory primary and junior school showed greater interest in biology than boys. Whereas Israelis boys who were graduates of compulsory primary and junior school recorded higher interest in physics than girls (Trumper, 2006b). However, Kurbanoğlu and Arsian found no gender difference in the career interest of 702 high school students in Sakarya. Therefore, this study examined the moderating effects of FCIS and gender on students' acquisition of SPSs in BS using SL and ELGM experiments in junior secondary three in Oyo State, Nigeria.

\section{Hypotheses}

The following null hypotheses guided the study:

H1: There is no significant main effect of future career interest in science on students' acquisition of science process skills in Basic Science.

H2: There is no significant main effect of gender on students' acquisition of science process skills in Basic Science.

H3: There is no significant interaction effect of future career interest in science and gender on students' acquisition of science process skills in Basic Science.

\section{METHODOLOGY}

This study adopted the pretest-posttest control group quasi-experimental design with a $3 \times 2 \times 2$ factorial matrix. A total of 277 junior secondary three students from six intact classes and six previously trained research assistants who were randomly selected from six purposively chosen co-educational schools in six local government areas of Oyo State participated in the study. Two of the selected schools have functional computer laboratories, two other schools have well-equipped physics laboratories and the remaining two schools have conventional (expository/demonstrational) laboratory facilities in light and electrical energy. Experiments on reflection of light as well as relationship between potential difference and electric current were purposively selected for the study. This is because the report of a preliminary survey among BS teachers in Oyo State indicated light and electrical energy as two of the perceived difficult topics which are either not or poorly taught by the teachers. The two topics are under the theme: "You and Energy" in JSIII of the Nigeria Educational Research and Development Council (NERDC) BS curriculum.

Six of the seven research instruments developed by Ogunkunle (2017) were adopted for use in the study. They include: Instructional Guide on Simulated Laboratory Experiments (IGSLE), Instructional Guide on Enriched Laboratory Guide Material Experiment (IGELGME), Instructional Guide on Conventional (expository) Laboratory Experiments (IGCELE), Science Process Skills Test in BS (SPSTBS) with KR-20 reliability index of 0.72 , Future Career Interest in Science Questionnaire (FCISQ) with Cronbach's alpha reliability index of 0.99 and Research Assistants Training Evaluation Scale (RATES). Students' acquisition of three basic SPSs (classifying, measuring and predicting) and four integrated SPSs (defining variables operationally, identifying experimental variables, organizing data through construction of appropriate tables of values/readings and describing relationships between variables -inferring) were examined in this study. FCISQ and SPSTBS were administered to the sampled students. They were exposed to appropriate treatments in SL and ELGM experiments on the basis of the schools for seven weeks. The two instruments were re-administered to the students at the end of the treatments. The data collected were analysed using Analysis of Covariance (ANCOVA) with the pretest scores as covariates to test the hypotheses at $p<.05$ level of significance. Estimated Marginal Means (EMM) was computed in order to detect differences between the pretest and posttest mean scores for different groups.

\section{RESULTS}

H1: There is no significant main effect of future career interest in science on students' acquisition of science process skills in Basic Science.

Table 3 shows that there was a significant main effect of future career interest in science on students' acquisition of science process skills in Basic Science $(F(1,264)=17.62$, $p<.05$; partial $\eta^{2}=.063$ ). This implies that the future career interest in science had a significant main effect on students' 
acquisition of science process skills posttest mean score in Basic Science, with an effect size of $6.3 \%$. Therefore, $\mathrm{H} 1$ is rejected. In order to determine how the groups performed, the Estimated Marginal Means were computed and these are presented in Table 4.

TABLE 3. Summary of ANCOVA

\begin{tabular}{|c|c|c|c|c|c|c|}
\hline Source & Type III Sum of Squares & $D f$ & Mean Square & $\boldsymbol{F}$ & Sig. & Partial Eta Squared \\
\hline Corrected Model & $536.236^{\mathrm{a}}$ & 12 & 44.686 & 8.471 & .000 & .278 \\
\hline Intercept & 9386.701 & 1 & 9386.701 & 1779.366 & .000 & .871 \\
\hline Pre-Science Process Skills & 8.409 & 1 & 8.409 & 1.594 & .208 & .006 \\
\hline \multicolumn{7}{|l|}{ Main Effect } \\
\hline Future Career Interest in Science & 92.948 & 1 & 17.619 & $.000 *$ & .063 & \\
\hline Gender & 9.008 & 1 & 9.008 & 1.708 & .192 & .006 \\
\hline \multicolumn{7}{|l|}{ 2-Way Interaction } \\
\hline \multicolumn{7}{|l|}{ Future Career Interest in Science } \\
\hline x Gender & & 1 & .425 & .081 & .777 & .000 \\
\hline Residual (Error) & .425 & 264 & 5.275 & & & \\
\hline Total & 1392.680 & 277 & & & & \\
\hline \multirow[t]{2}{*}{ Corrected Total } & 58627.000 & 276 & & & & \\
\hline & 1928.917 & & & & & \\
\hline
\end{tabular}

a. $R$ Squared $=.278($ Adjusted $R$ Squared $=.245) *$ Significant at $p<.05$

TABLE 4. Estimated Marginal Means

\begin{tabular}{llllll}
\hline \hline Group & \multirow{N}{*}{ Mean } & Std.Error & \multicolumn{2}{l}{$\mathbf{9 5 \%}$ Confidence Interval } \\
\cline { 5 - 6 } & & & & Lower Bound & Upper Bound \\
\hline 1. Science-related & 197 & $14.809^{\mathrm{a}}$ & .169 & 14.476 & 15.143 \\
2. Non-Science related & 80 & $13.356^{\mathrm{a}}$ & .302 & 12.762 & 13.951 \\
\hline \hline
\end{tabular}

a. Covariates appearing in the model were evaluated at Pre-Science Process Skills' Acquisition score $=5.8700$

Table 4 reveals that students with science-related future career interest in science group had higher posttest science process skills acquisition mean score (14.81) in Basic Science than the non-science related group $(\bar{X}=13.36)$. This implies that students in the science-related future career interest in science group acquired more science process skills than those in the non-science related group.

H2: There is no significant main effect of gender on students' acquisition of science process skills in Basic Science.
Table 3 reveals that there was no significant main effect of gender on students' acquisition of science process skills in Basic Science $(F(1,264)=1.71, p<.05)$. This implies that gender had no significant main effect on students' posttest acquisition of science process skills in Basic Science. Therefore, $\mathrm{H} 2$ is not rejected. In order to determine how the groups performed, the Estimated Marginal Means were computed and these are presented in Table 5.

TABLE 5. Estimated Marginal Means of Posttest Science Process Skills' Acquisition

\begin{tabular}{llllll}
\multicolumn{7}{c}{ Scores in Basic Science by Gender } \\
\hline \hline Group & $\boldsymbol{N}$ & Mean & \multirow{2}{*}{ Std.Error } & \multicolumn{2}{l}{$\mathbf{9 5 \%}$ Confidence Interval } \\
\cline { 3 - 6 } & & & & Lower Bound & Upper Bound \\
\hline 1. Male & 130 & $14.309^{\mathrm{a}}$ & .269 & 13.779 & 14.839 \\
2. Female & 147 & $13.856^{\mathrm{a}}$ & .218 & 13.427 & 14.286 \\
\hline \hline
\end{tabular}

a. Covariates appearing in the model were evaluated at Pre-Science Process Skills' Acquisition score $=5.8700$ 
Table 5 shows that male students have superior posttest science process skills' acquisition mean score (14.31) than female students $(\bar{X}=13.86)$.

H3: There is no significant interaction effect of future career interest in science and gender on students' acquisition of science process skills in Basic Science.

Table 3 shows that there was no significant 2-way interac- tion effect of gender and future career interest in science on students' acquisition of science process skills in Basic Science $(F(1,264)=.08, p<.05)$. Therefore, $\mathrm{H} 3$ is not rejected. In order to determine how the groups performed, the Estimated Marginal Means were computed and these are presented in Table 6.

TABLE 6. Estimated Marginal Means of Posttest Science Process Skills' Acquisition Scores in Basic Science by Gender

\begin{tabular}{lllllll}
\hline \hline Group & & $\boldsymbol{N}$ & Mean & Std.Error & \multicolumn{2}{c}{ text95\% Confidence Interval } \\
Future Career in Science & Gender & & & & Lower Bound & Upper Bound \\
\hline 1. Science-related & Male & 96 & $15.085^{\mathrm{a}}$ & .248 & 14.597 & 15.572 \\
& Female & 101 & $14.534^{\mathrm{a}}$ & .231 & 14.079 & 14.989 \\
2.Non-Science related & Male & 34 & $13.533^{\mathrm{a}}$ & .478 & 12.593 & 14.474 \\
& Female & 46 & $13.179^{\mathrm{a}}$ & .370 & 12.451 & 13.907 \\
\hline \hline
\end{tabular}

a. Covariates appearing in the model were evaluated at Pre-Science Process Skills' Acquisition score $=5.8700$

Table 6 indicates that male students with science-related future career interest in science and those with non-science related future career interest in science had higher posttest mean scores in science process skills' acquisition in Basic Science $(15.09>14.53$ and $13.53>13.18)$ than their respective female counterparts.

\section{DISCUSSION}

\section{Effect of FCIS on Students' Acquisition of SPSs in Basic Science}

The findings of this study showed that FCIS had significant effect on students' acquisition of SPSs in BS. This implies that FCIS enhanced students' acquisition of SPSs in BS. This is because FCIS determines students' active participation in science activities (Hasni \& Potvin, 2015) through which students could develop SPSs (Utami et al., 2017). It becomes evident in the higher SPSs acquisition in BS by the sciencerelated future career interest than non-science related future career interest in science.

\section{Effect of Gender on Students' Acquisition of SPSs in Ba- sic Science}

The result obtained in this study indicated that students' acquisition of SPSs in BS was not significantly affected by gender. This implies that male and female BS students either have not significantly acquired or have developed SPSs in almost equal proportion. Light and electricity experiments were used in the study and they form parts of topics in post- basic education physics curriculum. Trumper (2006a), Trumper (2006b) observed that Israelis girls are more interested in the study of biology whereas their boys are more inclined to the study of physics. This is suggestive of gender difference in active participation in the study and better acquisition of SPSs by males than females. However, the result of this study contradicts the observation made by Ige and Fasasi (2009) that Nigeria senior secondary two male students acquired more practical skills in agricultural science than females. Also, it does not support the report of Akani (2005) that male final year students in Nigeria colleges of education possess significantly more SPSs than females.

\section{Interaction Effect of FCIS and Gender on Students' Ac- quisition of SPSs in Basic Science}

The interaction effect of FCIS and gender on students' acquisition of SPSs in BS was found not to be significant. This implies that FCIS and gender did not collectively determine acquisition of SPSs in BS. This is because practical work is intrinsically interesting to both male and female students (Ogunbowale, 2012) and the use of simulations make science lessons more exciting for both teachers and students (Ige \& Ele, 2009).

\section{CONCLUSION}

The study revealed that students' acquisition of SPSs in BS does not depend on gender but FCIS. This implies that encouraging students to participate in science should not be based on gender consideration. However, FCIS of students should determine the selection of instructional materials for lesson delivery. Since many students are usually fascinated by information and communication technology gadgets, schools should be encouraged to adopt the use of SL ex- 
periments as viable alternative to make students participate in laboratory activities especially in Nigeria where there are no BS laboratories in schools. Also, well planned and logically organised activity-based lessons save time, develop students' interest and promote meaningful learning. Thus, ELGMs should be adopted for the conduct of laboratory experiments. This will improve SPSs acquisition.

\section{RECOMMENDATIONS}

Based on the findings of the study, the following recommendations were made.

1. Government through the ministry of education should emphasize the development of SPSs in BS through students' active involvement in activity-based laboratory instruction. 2. BS teachers should endeavour to conduct a survey of the FCIS of students and utilise the information to motivate them to participate in laboratory experiments.

3. BS teachers should give equal attention and assistance to students' learning challenges irrespective of gender.

4. Government and other stakeholders in education should encourage the development and production of SL experiments and ELGMs in other BS topics than light and electricity.

5. Schools should adopt the use of SL experiments as viable alternative to conducting BS experiments where there are no functional science laboratories.

\section{REFERENCES}

Ajeyalemi, D. (2011). Practical work in school science: Are the aims and objectives being achieved. STAN Memorial lecture presented at the 52nd Annual Conference of the Science Teacher Association of Nigeria, Akure, Nigeria.

Akani, O. (2005). Levels of possession of science process skills by final year students of colleges of education in south-western states of Nigeria. Journal of Education and Practice, 6(27), 94-101.

Akinbobola, A. O., \& Afolabi, F. (2010). Analysis of science process skills in [West African senior secondary school certificate physics practical examinations in Nigeria. American-Eurasian Journal of Scientific Research, 5(4), 234-240.

Aktamis, H., \& Ergin, 0. (2008). The effect of scientific process skills education on students' scientific creativity, science attitudes and academic achievements. In Asia-Pacific Forum on Science Learning and Teaching, Hong Kong.

Aydogdu, B., Erkol, M., \& Erten, N. (2014). The investigation of science process skills of elementary school teachers in terms of some variables: Perspectives from Turkey. Asian-Pacific Forum on Science Learning and Teaching, 15(1), 1-29. doi:https://doi.org/10.5897/err2015.2097

Blough, G., \& Schwartz, J. (1974). Elementary school science and how to teach it. New York, NY: Holt McDougal.

Chebii, R., Wachanga, S., \& Kiboss, J. (2012). Effects of science process skills mastery learning approach on students' acquisition of selected chemistry practical skills in school. Creative Education, 3(08), 1291-1296. doi:https://doi.org/ $10.4236 /$ ce.2012.38188

Cheung, D. (2018). The key factors affecting students' individual interest in school science lessons. International Journal of Science Education, 40(1), 1-23. doi:https://doi.org/10.1080/09500693.2017.1362711

Ekpunobi, A. (2005). The challenge of science, technology and mathematics teaching in the implementation of UBE programme. In A paper presented at the Niger state STAN Conference, California, CA.

Eya, N., \& Elechi, C. (2011). Availability of basic science laboratory facilities in junior secondary schools: A panacea for reform in stem education. In STAN Conference Proceedings, California, CA.

Hasni, A., \& Potvin, P. (2015). Students' interest in science and technology and its relationships with teaching methods, family context and self-efficacy. International Journal of Environmental and Science Education, 10(3), 337-366.

Hidi, S., \& Renninger, A. (2006). The four-phase model of interest development. Educational Psychologist, 41(6), 111-127. doi:https://doi.org/10.1207/s15326985ep4102_4

Hofstein, A., \& Lunetta, V. N. (2004). The laboratory in science education: Foundations for the twenty first century. Science Education, 88(1), 28-54. doi:https://doi.org/10.1002/sce.10106

Ige, T., \& Ele, E. O. (2009). Teachers' awareness and extent of utilization of information and communication technology for science teaching in Ogun state. Nigeria Journal of Computer Literacy, 10(1), 56-84.

Ige, T., \& Fasasi, R. (2009). Comparative effects of laboratory work and field work on students' practical skills acquisition in agricultural science. African Journal of Educational Research, 13(1), 194-202.

İzzet Kurbanoğlu, N., \& Arslan, S. (2015). High school students' educational and career interest (science-technologymathematics) and career adaptabilities. Australian Journal of Career Development, 24(3), 166-172. doi:https:// doi.org/10.1177/1038416215594633 
Kazeni, M. M. M. (2005). Development and validation of a test integrated science process skills for the further education and training learners (Unpublished master's thesis). University of Pretoria, Pretoria, South Africa.

Keong, C. S., Yip, M. W., Swee, N. S. L., Toh, G. G., \& Tai, S. C. (2017). A review of TRIZ and its benefits \& challenges in stimulating creativity in problem solving of pre-university students: A TARUC case study. Journal of Advances in Humanities and Social Sciences, 3(5), 247-263. doi:https://doi.org/10.20474/jahss-3.5.2

Lazarowitz, R., \& Huppert, J. (2014). Science process skills of 10th-grade biology students in a computer-assisted learning setting. Journal of Research on Computing in Education, 25(3), 366-382. doi:https://doi.org/10.1080/08886504.1993 .10782057

Nigerian Educational Research and Development Council. (2012). Basic science and technology teacher capacity development: Beyond pedagogy. Retrieved from https://bit.ly/2WQtsui (accessed on 15 July, 2018)

Ogunbowale, M. (2012). Biology laboratory facilities and teachers' job performance in selected secondary schools in Ogun state. COEASU Journal of Multidisciplinary Studies, 3(1), 471-476.

Ogunkunle, S. J. (2017). Effects of simulated laboratory and enriched laboratory guide material experiments on students' learning outcomes in basic science in Oyo State, Nigeria (Unpublished doctoral thesis). University of Ibadan, Ibadan, Nigeria.

Ostlund, K. L. (1992). Science process skills: Assessing hands-on student performance. New York, NY: Addison-Wesley.

Oyo State Government. (2015). Department of planning research and statistics. Retrieved from https://urlzs . com/8uR3 (Accessed on 15 July, 2018)

Ozgelen, S. (2012). Students' science process skills within a cognitive domain framework. Eurasia Journal of Mathematics, Science and Technology Education, 8(4), 283-292. doi:https://doi.org/10.12973/eurasia.2012.846a

Padilla, M. J., Okey, J. R., \& Dillashaw, F. G. (1983). The relationship between science process skill and formal thinking abilities. Journal of Research in Science Teaching, 20(3), 239-246. doi:https://doi.org/10.1002/tea.3660200308

Rex, O. O., Yetunde, O., Grace, E. C., \& Pearl, O. A. (2017). Sustainable urbanization: Investigating problems encountered in uncontrolled urban growth in Nyanya - a suburb of Abuja, Nigeria. International Journal of Humanities, Arts and Social Sciences, 3(1), 13-19. doi:https://doi.org/10.20469/ijhss.3.20003-1

Shaheen, J., \& Khattab, K. (2005). School lab and its role in science instruction. Retrieved from https://bit. Iy/2UyDpyV (accessed on 14 July, 2017)

Tobin, K. G., \& Capie, W. (1982). Relationships between formal reasoning ability, locus of control, academic engagement and integrated process skill achievement. Journal of Research in Science Teaching, 19(2), 113-121. doi:https://doi.org/ $10.1002 /$ tea.3660190203

Trumper, R. (2006a). Factors affecting junior high school students' interest in biology. Science Education International, 17(1), 31-48. doi:https://doi.org/10.1007/s10956-006-0355-6

Trumper, R. (2006b). Factors affecting junior high school students' interest in physics. Journal of Science Education and Technology, 15(1), 47-58.

Utami, B., Saputro, S., Ashadi, M. M., Yamtinah, S., \& Widoretno, S. (2017). Development of the science skills of lower secondary students in a chemistry laboratory experiment. Pertanika Journal of Social Science and Humanities, 25(4), 41-50. doi:https://doi.org/10.9790/0837-19624145

Yang, K.-Y., \& Heh, J.-S. (2007). The impact of internet virtual physics laboratory instruction on the achievement in physics, science process skills and computer attitudes of 10th-grade students. Journal of Science Education and Technology, 16(5), 451-461. doi:https://doi.org/10.1007/s10956-007-9062-6

Zeidan, A., \& Jayosi, M. (2015). Science process skills and attitudes toward science among Palestinian secondary school students. World Journal of Education, 5(1), 13-24. doi:https://doi.org/10.5430/wje.v5n1p13 